\title{
Editorial
}

\section{O traço e a meta}

O talento de colocar em expressão o humor associado ao objetivo de interpretar fatos da vida cotidiana leva a resultados de produção comunicacional em que se promove lazer com expansão de consciência e aperfeiçoamento da capacidade de leitura. Com seu olhar hábil e de longo alcance, o profissional dedicado à arte de produzir charges, cartuns, HQs e quaisquer outras peças de humor gráfico, contribui com um ato transformador que converte esse olhar em expressão hilária. Ele é um tipo leitor que se adianta aos demais e, a seguir, age como um tradutor do que se passa ao redor para a mente de quem é atingido pela arte de seu trabalho. O dossiê temático desta edição da revista Discursos Fotográficos contém estudos que tratam, de modo científico, essa relação entre o artista e seu público e o potencial que o manejo de linguagens assim realizado adquire e mobiliza.

A experiência do site Cartoon Movement é retratada com relação às contribuições institucionais que oferece e é destacada como componente caracterizador do jornalismo em quadrinhos na web em suas dimensões editorial, institucional e comercial. $\mathrm{O}$ texto aponta também a conduta colaborativa, a independência editorial e a diversidade de vozes, ao refletir valores institucionais. As adaptações cômicas em metáforas encontradas no humor digital são focalizadas em outro artigo, cuja ênfase está em fazer compreender a razão pela qual imagens de contestação política, ao circularem fora do ambiente regular de edição, criam uma propagação, por meio da chamada piada viral (meme), de sentimentos coletivos capazes de ultrapassar o alcance do espaço de acesso a que todos estão habituados.

A importância simbólica de um dos mais notáveis líderes mundiais, tratada pelo discurso chárgico, é estudada no artigo que discute o valor discursivo dessa associação. Um conjunto de charges produzidas na África do Sul nas quais se promove uma homenagem póstuma a Nelson Mandela revela, não só essa face, como também fornece elementos concretos da historiografia sul-africana. Ainda no campo político, o artigo seguinte faz referência à trágica condição dos refugiados em busca de asilo, pondo em evidência a fotografia do menino Aylan Kurdi transformada em caricatura 
pelo não menos trágico periódico Charlie Hebdo. A fotografia é analisada por meio da ideia de disfunção narcotizante, como decorrência de seu papel nos regimes de visibilidade.

Cinco outros artigos trazem reflexões para uma seção reservada a outros temas além daqueles do dossiê temático. $\mathrm{O}$ primeiro apresenta e analisa o banco de dados constituído pelos arquivos de Pedro Meyer, em que se penetra nos bastidores de sua obra para conhecer o processo criativo entendido não como dirigido a um produto final, mas como algo inacabado e incompleto em contínua construção como significação. Os processos de criação encontram, no artigo seguinte, um exemplar tratamento para a fotografia focalizada no contexto da experimentação contemporânea, em que as interações por ela promovidas permitem um olhar sobre os procedimentos fotográficos agregado a temas como processos de fotógrafos, fotografia de passagem, registros de processos e exploração de arquivos.

Um artigo que aborda a fotografia como portadora da voz de estudantes de administração ao dizerem, por meio de imagens, o modo como veem a universidade, revela, fazendo uso da metodologia da análise de conteúdo, o caráter multifacetado, ambíguo e complexo encontrado nessa observação. A cultura visual é retratada no artigo que discute a exposição do corpo associada a gênero em publicidades veiculadas em revistas sobre estilo de vida. Conclui esta edição um estudo sobre discurso fotográfico no livro didático e suas implicações nas práticas de leitura. Três pensadores de teoria da linguagem são trazidos como referência e, por meio de suas fundamentações, são apontados riscos a exigir atenção nas ditas produções.

A (re)educação do olhar constitui um inestimável ganho de competência, e cabe pensar numa "desautomatização" do olhar diante da imagem. O discurso chárgico carrega em si uma concentração de elementos de largo espectro para quebrar o que vem maquinalmente pela força do hábito, pelos processos inconscientes e involuntários. $\mathrm{O}$ mesmo se pode afirmar do discurso fotográfico que também incorpora uma força ativa capaz de tocar sentimento e razão. Conhecer sempre mais a respeito do funcionamento de todos esses processos é a motivação da ciência que aqui se compartilha.

Tenha uma boa leitura. 